\title{
Guideline for the immunization of HIV infected persons in Sri Lanka
}

\author{
Dr. M. K. Darshanie Mallikarachchi, Consultant Venereologist, \\ Provincial General Hospital Ratnapura. Email: darshanie.mallikarachchi@gmail.com, \\ (D) https://orcid.org/0000-0002-0355-8400,
}

This article is also published in the SLMA Guidelines and information on Vaccines 6th edition 2017

Immunization is an important measure to protect people living with HIV/AIDS (PLHIV) against certain vaccine preventable diseases. PLHIV often have an increased risk of infection and they could experience more severe disease compared to HIV uninfected persons. However as HIV infection alters immune function, vaccination of HIV-infected persons may not confer the same degree of protection gained by immunocompetent persons. The antibody response is frequently impaired in PLHIV, as the virus attacks the CD4 $\mathrm{T}$ cell, which is important in antibody formation. However, many of these vaccines still afford protection but the immunity may remain lower and decline more rapidly compared to HIV negative individuals. To overcome this issue, some vaccines could be administered with a modified schedule such as higher or more frequent doses which improves the immunogenicity ${ }^{1}$. In addition certain vaccines enhance HIV virus replication and transiently increase HIV viral load but this does not preclude vaccination ${ }^{2}$.

Theoretically, for PLHIV, the vaccine should be given before the immune status of the patient is suppressed. Persons with severe immunodeficiency* may have impaired humoral response, and may not respond to vaccines or they may require supplemental doses to develop serological evidence of protection. If possible, vaccines should be administered before the CD4 count decreases to $<200$ cells $/ \mu \mathrm{L}$.

In general all inactivated vaccines could be administered safely to persons with altered immunocompetence ${ }^{3}$.

However live vaccines such as BCG, oral polio, measles, mumps, rubella, varicella and yellow fever vaccines may pose a risk to HIV infected individuals. Nevertheless, antiretroviral therapy (ART) induced immune restoration reduces the possibilities of having adverse effects and shifts the risk benefit ratio in favour of vaccination. Therefore, live vaccines such as varicella (VZV), yellow fever and MMR could be considered for individuals whose immunity is not severely compromised or is restored with ART (children with CD4 T lymphocyte cell percentage $>15 \%$ and those aged $>5$ years with CD4 counts $\geq 200$ cells $/ \mu \mathrm{L})^{3}$. Before administering live vaccines consultation with an immunologist or a vaccinologist is advised.

* HIV-infected persons $>5$ years of age with CD4 percentage $<15 \%$ and CD4 counts $<200$ cells $/ \mu \mathrm{L}$. Children $\leq 5$ years of age with $\mathrm{CD} 4$ percentage $<15 \%$ are considered to have severe immunosuppression

General principles of immunization in HIVinfected children

Vaccines may be less effective in HIV infected children. However, these children also have an increased risk of disease and may have more severe illness if they are infected. Therefore, HIV infected children should be protected from vaccine preventable diseases. Hence completing immunization is important, but consideration should be given to the most appropriate time for immunization. It is important to immunize the HIV infected children prior to the impairment of their immune system or after immune reconstitution occurs with ART. 
General principles of immunization in HIVinfected adults

Live vaccines

- Persons with symptomatic HIV infection or CD4 counts $<200$ cells $/ \mu \mathrm{L}$ should not be given live vaccines. Vaccination may be reconsidered when immune restoration occurs with $A R T^{1}$.

- HIV infected adults with a CD4 count of 200-300 cells/ $\mu \mathrm{L}$ have a moderate immunodeficiency ${ }^{1}$. When administering live vaccines for them it is important to weigh the risk and benefits before vaccination.

- Co-administration of multiple live vaccines to HIV infected individuals is not recommended due to issues related to safety, immunogenicity and efficacy. It is recommended to have at least an interval of four weeks between vaccination ${ }^{1}$.

\section{Inactivated vaccines}

- In persons with CD4 counts $<200$ cells $/ \mu \mathrm{L}$, the response to inactivated vaccines is reduced $^{1}$. Delaying vaccination till immunorestoration could be considered in these patients. However if the risk of exposure is high, vaccination could be done. If indicated vaccination could be repeated following immunorestoration on ART.

\section{Recommendation for pre-exposure vaccination in HIV-infected adults ${ }^{1}$}

\section{Haemophilus influenzae type b vaccine (Hib)}

Vaccine has been shown to produce protective antibodies in HIV infected individuals but the response can vary with the CD4 cell count. It is recommended that HIV positive individuals with asplenia, splenic dysfunction, or complement deficiency should receive one dose of a Hib containing vaccine whether or not they were immunized previously and regardless of CD4 count, ART use and viral load ${ }^{1}$.

\section{Hepatitis A vaccine}

It is recommended to do pre-vaccination screening for hepatitis A immunity in HIV positive adults who are at risk of hepatitis $A$. Following categories could be considered as at risk for hepatitis A infection.

- Close contacts with Hepatitis A

- Men who have sex with men

- Injecting and non-injecting drug users

- Those with occupational exposure to Hepatitis A

- Persons who require frequent blood /blood products transfusions

- Persons with special needs living in residential institutions and their carers

If serologically negative for hepatitis A, they should be offered monovalent hepatitis $A$ vaccine. The immune response to hepatitis $A$ vaccine is generally reduced in HIV positive individuals compared to HIV negative individuals. But the response improves with increasing CD4 cell counts and viral load suppression on ART. The vaccine is safe and well tolerated in HIV positive individuals including those who receive three doses over 6 months.

\section{Hepatitis B vaccine}

HIV infection affects the response to Hepatitis $B$ vaccine and the HBsAb seroconversion strongly correlates with $\mathrm{CD} 4$ cell count and viral load. Revaccination of nonresponders once the CD4 count is $>350$ cells/ $\mu \mathrm{L}$, suppression of viral load with ART and the use of larger and more frequent vaccine doses are some strategies available to improve the vaccine response among HIV infected individuals. Duration of vaccine induced protection is unknown in HIV positive individuals and in general, post vaccination antibody levels are lower and disappear more quickly than in HIV uninfected individuals.

When using recombinant vaccines, high dose (40 $\mu \mathrm{g},-2$ doses of $20 \mu \mathrm{g} / \mathrm{ml}$ vaccine) vaccination should be offered. Four vaccine doses should be given at $0,1,2$, and 6 months ${ }^{1}$. It is recommended to measure the 
HBsAb levels 4-8 weeks after the last vaccine dose.

Antibody level $>100 \mathrm{IU} / \mathrm{L}$ are regarded as ideal, whereas a level $<10 \mathrm{IU} / \mathrm{L}$ is classified as nonresponsive. It is recommended that individuals with HBsAb levels $\geq 10$ but $<100$ IU/L should receive one booster dose ${ }^{1}$. If retesting of $\mathrm{HBsAb}$ level shows antibody level between $\geq 10-100 \mathrm{IU} / \mathrm{L}$ regular annual HBsAb testing is needed to guide subsequent boosting requirement.

Individuals who have HBsAb levels $<10 \mathrm{IU} / \mathrm{L}$ after the primary vaccine course should receive three further vaccine doses at monthly intervals. It is better to delay the revaccination until the viral load is suppressed on ART and the CD4 count has increased > 350 cells $/ \mu \mathrm{L}$.

Screening of HBsAb levels with longer intervals (2-4 yearly) are indicated for individuals with initial HBsAb levels $>100 \mathrm{IU} / \mathrm{L}$, CD4 count $>350$ cells $/ \mu \mathrm{L}$ and viral load suppression on ART. Other individuals should undergo yearly HBsAb screening.

\section{Human papillomavirus vaccine}

HIV infected individuals are at higher risk of HPV acquisition, persistence and at increased risk of HPV related malignancies. The response to vaccine is highest in those receiving ART and showing high CD4 cell count and suppressed viral load. Studies are still on-going to demonstrate the duration of vaccine induced protection. Even though younger individuals are more likely to benefit from the vaccine, older men and women may continue to have at least a partial benefit from vaccination.

It is recommended that previously unvaccinated HIV infected men and women aged up to 26 years be offered HPV vaccination regardless of CD4 count, ART use and viral load. Previously unvaccinated HIV positive men having sex with men aged up to 40 years be offered HPV vaccination regardless of CD4 count, ART use and viral load $^{1}$.

It may be useful to offer HPV vaccination for previously unvaccinated HIV positive women aged up to 40 years regardless of CD4 count, ART use and viral load ${ }^{1}$. In ART naïve patients with CD4 cell count $<200$ cells $/ \mu \mathrm{L}$, vaccination may be postponed until the patient is established on ART.

\section{Inactivated polio vaccine}

Inactivated polio vaccine can produce neutralizing antibodies in HIV positive adults and children and in patients with CD4 count $<300$ cell $/ \mu \mathrm{L}$. It is safe and well tolerated. It is recommended that individuals who are unvaccinated should receive 3 vaccine doses at monthly interval followed by 2 reinforcing doses after 5 and 10 years ${ }^{1}$. Fully vaccinated individuals could receive booster doses every 10 years if at risk of exposure.

\section{Influenza vaccine}

Vaccine response is lower compared to HIV negative individuals and correlate with CD4 cell count and viral load. As patients with HIV infection are at higher risk of complications of influenza, it is recommended to offer annual inactivated influenza vaccine to all HIV infected individuals especially for HIV infected pregnant women.

\section{Japanese encephalitis vaccine}

Live JE vaccine is not recommended in HIV infected patients. There is insufficient evidence on the safety, immunogenicity and clinical efficacy of JE vaccination in HIV positive adults. However it is recommended that HIV infected individuals be offered an inactivated vero cell derived JE vaccine with two doses given 1 month apart. A booster dose could be given 1-2 years later for those at continued risk with a further booster planned after 10 years ${ }^{1}$. This vaccine is not available in Sri Lanka at present. 


\section{Meningococcal vaccine}

Patients with HIV infection are at higher risk of invasive meningococcal infection especially those with CD4 cell count $<200$ cells $/ \mu \mathrm{L}$ and viral load $>400$ copies $/ \mathrm{mL}$. However HIV infection alone is not currently an indication for meningococcal vaccine. It is recommended that HIV positive individuals who are close contacts of patients with meningococcal disease should be offered antibiotic prophylaxis and appropriate vaccination.

\section{MMR vaccine}

The prognosis of rubella and mumps does not show much difference between HIV infected individuals and the general population. However measles could be life threatening in persons with advanced HIV infection. Therefore, it is recommended to offer two doses of MMR vaccine at least 1 month apart to measles seronegative HIV infected patients with CD4 cell counts $>200$ cells $/ \mu \mathrm{L}$. However, based on the likelihood of exposure, vaccination may be postponed in patients with CD4 cell count $>200$ cells $/ \mu \mathrm{L}$ who have not started on ART.

After a significant exposure to measles, HIV infected individuals should be screened for measles IgG within 3 days regardless of a history of previous vaccination. After a risk assessment about the need and the mode of post exposure prophylaxis, measles seronegative adults:

- with CD4 count $>200$ cells/ $\mu \mathrm{L}$ preferably on ART with a stable viral load could receive MMR vaccine within 3 days of contact or IM preparation of human immunoglobulin (HNIG) within 6 days of contact $^{1}$.

- with CD4 counts $<200$ cells $/ \mu \mathrm{L}$ could be given HNIG within 6 days ${ }^{1}$.

However the protection afforded with HNIG/IVIG will be short lived.

It is also recommended to give MMR vaccine to rubella seronegative HIV positive women of child bearing age provided their CD4 count is $>200$ cells $/ \mu \mathrm{L}$ and they are not pregnant. Vaccine responses are reduced in HIV infected individuals but effective ART can improve the response.

\section{Pneumococcal vaccine}

HIV infected individuals are at higher risk of developing pneumococcal disease and show an increased risk of mortality. Studies conducted on clinical efficacy of pneumococcal polysaccharide vaccine (PPSV23) in HIV positive adults have shown inconsistent findings. However, serological studies conducted on pneumococcal conjugate (PCV) vaccine have shown immunogenicity in HIV infected persons ${ }^{1}$. With both vaccines, the response is low in HIV positive individuals compared to HIV negative individuals. However PCV vaccine has demonstrated superiority with certain serotypes over PPSV in serological studies ${ }^{1}$.

It is recommended to give pneumococcal vaccine to HIV infected individuals irrespective of the CD4 cell count, ART use and viral load.

One dose of PCV 13/10 could be administered followed by one dose of PPSV23 at least 8 weeks later. Second dose of PPSV23 should be administered at least 5 years after the previous dose. One final dose of PPSV23 should be administered at 65 years or older. This dose should be given at least 5 years after the most recent dose of PPSV2 $3^{4}$.

\section{Rabies vaccine}

When giving post exposure prophylaxis, each case should be assessed individually. Following categories should be considered as non-immune for rabies and should be given rabies immunoglobulin (RIG) and five doses of a cell culture derived vaccine intramuscularly at $0,3,7,14$ and 30 days $^{1}$.

- Unvaccinated

- Partially vaccinated ( $<3$ doses) 
- Given a complete course of vaccination (5 doses) but without serological evidence of an adequate antibody response

- Uncertain vaccination history

- $\quad$ CD4 cells $<500$ cells/ $\mu \mathrm{L}$ and not receiving ART

In patients who previously received 5 doses of the vaccine and had adequate antibody response with a CD4 count $>500$ cells $/ \mu \mathrm{L}$, viral suppression ( $>6$ months) and on ART may be managed with 2 intramuscular doses given at 0 and 3-7 days without RIG ${ }^{1}$.

After full course of vaccination all patients should undergo serological testing 2 weeks after the last vaccine dose and nonresponders are offered double dose or more frequent vaccine doses after obtaining specialist advice.

\section{Tetanus-Diphtheria vaccine (aTd)}

The HIV infected adults who require vaccination against tetanus and diphtheria could be given aTd vaccine regardless of CD4 cell count, ART use and viral load. It is recommended to give three vaccine doses at 1 month intervals, followed by 2 reinforcing doses after 5 and 10 years ${ }^{1}$.

\section{Tetanus toxoid}

The vaccine has been shown to be immunogenic in HIV infected individuals even though the response is less compared to HIV non infected individuals. However the immunity improves following successful ART.

If the patient is unvaccinated for tetanus, it is recommended to give the adult tetanus vaccine regardless of CD4 count, ART use and viral load in three vaccine doses given at 1 month intervals, followed by two reinforcing doses after 5 and 10 years. Fully vaccinated individuals should receive a booster dose every 10 years.
Following a potential exposure,

i. Individuals with uncertain or incomplete vaccination, 3 vaccine doses at monthly intervals should be given regardless of type of wound and level of risk.

ii. Individuals who have previously received three vaccine doses with a clean wound and negligible risk should receive one dose if the last dose received was $>10$ years previously.

iii. Individuals who received at least three vaccine doses with tetanus prone wound should receive tetanus immunoglobulin and 1 dose of vaccine if the last dose received was $>10$ years previously.

\section{Typhoid vaccine}

HIV infected individuals are at higher risk of developing infections with Salmonella and more likely to develop complications. It is recommended to offer $\mathrm{Vi}$ capsular polysaccharide vaccine to HIV infected individuals who are likely to be exposed to poor sanitary conditions. The vaccine should be given at least 2 weeks before the expected exposure. The booster dose could be given every 3 years for those who remain at risk.

\section{Varicella zoster vaccine}

HIV infected individuals who acquire chicken pox are at higher risk of developing severe and fulminant disease. In addition, they are at increased risk of developing VZV reactivation especially with low CD4 count and with a viral load of $>400$ copies $/ \mathrm{mL}$. Even with ART the disease burden is 3-5 times higher compared to HIV negative individuals.

Chicken pox vaccine has shown to be safe and immunogenic in children with asymptomatic or mildly symptomatic HIV infection. However, only limited data are available in HIV positive adults ${ }^{1}$.

Two doses of the varicella vaccine 3 months apart are recommended for varicella seronegative patients who have CD4 cell count $>200$ cells $/ \mu \mathrm{L}$, and on $\mathrm{ART}^{1}$. 
Yellow fever vaccine

It is recommended that HIV infected individuals aged $<60$ years and with CD4 cell count $>200$ cells $/ \mu \mathrm{L}$ who are planning to travel to countries in which there is risk of exposure should be offered the vaccination after counseling on benefits and risks of vaccination. One vaccine dose at least 2 weeks before travel is recommended ${ }^{1}$. Higher CD4 counts and a suppressed viral load on ART are likely to maximize safety and the efficacy of vaccination.

Table 1: Immunization schedule for HIV infected children**

\begin{tabular}{|c|c|c|c|}
\hline Age & Standard schedule & Child with HIV & Remarks \\
\hline $0-4$ weeks & BCG & $\begin{array}{l}\text { HIV infected infants should not } \\
\text { receive BCG vaccine. BCG should be } \\
\text { postponed till HIV is excluded in HIV } \\
\text { exposed infants }\end{array}$ & \\
\hline \multicolumn{4}{|c|}{ On completion of } \\
\hline 2 months & $\begin{array}{l}\text { Pentavalent (DTP-HepB- } \\
\text { Hib) \& OPV } \\
\left(1^{\text {st }} \text { dose }\right) \\
\text { fIPV (fractional IPV) } \\
\left(1^{\text {st }} \text { dose }\right)\end{array}$ & $\begin{array}{l}\text { Pentavalent (DTP-HepB- } \\
\text { Hib)+inactivated polio vaccine } * * * \\
\left(1^{\text {st }} \text { dose }\right) \\
\text { Pneumococal conjugate vaccine } \\
(\text { PCV })-1^{\text {st }} \text { dose }\end{array}$ & \\
\hline 4 months & $\begin{array}{l}\text { Pentavalent (DTP-HepB- } \\
\text { Hib)\& OPV } \\
\left(2^{\text {nd }} \text { dose }\right) \\
\text { fIPV (fractional IPV) } \\
\left(2^{\text {nd }} \text { dose }\right)\end{array}$ & $\begin{array}{l}\text { Pentavalent (DTP-Hep B- } \\
\text { Hib)+inactivated polio vaccine }{ }^{* * *} \\
\left(2^{\text {nd }} \text { dose }\right) \\
\text { PCV }-2^{\text {nd }} \text { dose }\end{array}$ & \\
\hline 6 months & $\begin{array}{l}\text { Pentavalent (DTP-HepB- } \\
\text { Hib)\& OPV } \\
\left(3^{\text {rd }} \text { dose }\right)\end{array}$ & $\begin{array}{l}\text { Pentavalent (DTP-HepB-Hib)+ } \\
\text { inactivated polio vaccine*** } \\
\left(3^{\text {rd }} \text { dose }\right) \\
\text { PCV }-3^{\text {rd }} \text { dose }\end{array}$ & \\
\hline 9 months & MMR & MMR & $\begin{array}{l}\text { MMR- should be postponed in } \\
\text { severe immuno deficiency }\end{array}$ \\
\hline 12 months & Live JE & $\begin{array}{l}\text { Hep A 1st dose }\left(2^{\text {nd }} \text { dose } 6-12\right. \\
\text { months apart) }\end{array}$ & $\begin{array}{l}\text { Live JE is not recommended for HIV } \\
\text { infected children } \\
\text { Children with severe } \\
\text { immunosuppression may have a } \\
\text { suboptimal response to Hep A } \\
\text { vaccine }\end{array}$ \\
\hline 13-15 months & & $\begin{array}{l}\text { Varicella }-2 \text { doses } 3 \text { months apart } \\
\text { PCV booster dose }\end{array}$ & $\begin{array}{l}\text { Patients who are severely } \\
\text { immunosuppressed should not } \\
\text { receive the vaccine. }\end{array}$ \\
\hline 18 months & DTP\& OPV $\left(4^{\text {th }}\right.$ dose $)$ & DTP+Inactivated Polio vaccine ${ }^{* * *}$ & \\
\hline 3 years & MMR $2^{\text {nd }}$ dose & MMR $2^{\text {nd }}$ dose & $\begin{array}{l}\text { Patients who are severely } \\
\text { immunosuppressed should not } \\
\text { receive the vaccine. }\end{array}$ \\
\hline 5 years & $\mathrm{DT}+\mathrm{OPV}$ & $\begin{array}{l}\text { DT+Inactivated polio*** } \\
\text { Pneumococcal polysaccharide } \\
\text { vaccine (PPSV) booster }\end{array}$ & \\
\hline $\begin{array}{lr}10 & \text { years } \\
\text { (females } & \text { and } \\
\text { males } & \\
\end{array}$ & $\begin{array}{l}\text { HPV (quadrivalent) } \\
2 \text { doses } \\
\text { ( } 0,6 \text { months) }\end{array}$ & $\begin{array}{l}\text { HPV (quadrivalent) } \\
3 \text { doses } \\
\text { (0,2,6 months) }\end{array}$ & \\
\hline 11 years & aTd & aTd & \\
\hline
\end{tabular}


Table 2: Vaccination of adults with HIV

\begin{tabular}{|c|c|c|c|c|}
\hline Vaccine & Indication & Primary course & Boosting & Remarks \\
\hline $\begin{array}{l}\text { H. influenzae type b } \\
\text { (Hib) }\end{array}$ & At risk & Single dose & None & $\begin{array}{l}\text { Could be given regardless of } \\
\text { the CD4 cell count }\end{array}$ \\
\hline Hepatitis A & At risk & Two or three doses & Ten yearly if at risk. & $\begin{array}{l}\text { Three doses at } 0,1 \text {,and } 6 \\
\text { months if the CD } 4 \text { cell count is } \\
<350 \text { cells/ } / \mathrm{L} \text { and two doses at } \\
0 \text { and } 6 \text { months if the CD } 4 \text { cell } \\
\text { count is }>350 \text { cells } / \mu \mathrm{L} \text {. }\end{array}$ \\
\hline Hepatitis B & All non immune & $\begin{array}{l}\text { Four doses**** } \\
\text { (at } 0,1,2,6 \text { months) }\end{array}$ & $\begin{array}{l}\text { If } \mathrm{HBsAb} \geq 10-<100 \mathrm{IU} / \mathrm{L} \\
\text {-need one booster } \\
\text { dose and retesting If } \\
\mathrm{HBsAb} \leq 10 \mathrm{IU} / \mathrm{L} \text { need } \\
\text { three further vaccine } \\
\text { doses and retesting }\end{array}$ & $\begin{array}{l}\text { Could be given at all CD4 cell } \\
\text { counts. Screen HBsAb levels } \\
\text { according to initial response. }\end{array}$ \\
\hline $\begin{array}{l}\text { Human } \\
\text { papillomavirus }\end{array}$ & $\begin{array}{l}\text { Age and gender } \\
\text { related }\end{array}$ & $\begin{array}{l}\text { Three doses of } \\
\text { quadrivalent vaccine } \\
0,2 \text { and } 6 \text { months apart }\end{array}$ & None & $\begin{array}{l}\text { Could be given regardless of } \\
\text { the CD4 cell count }\end{array}$ \\
\hline Inactivated polio & $\begin{array}{l}\text { To all non } \\
\text { immune }\end{array}$ & $\begin{array}{l}\text { Five doses } \\
\text { (at 0,1,2 months, } 5 \\
\text { years and } 10 \text { years) }\end{array}$ & Ten yearly if at risk & $\begin{array}{l}\text { Could be given regardless of } \\
\text { the CD4 cell count }\end{array}$ \\
\hline Influenza & For all & Single dose & Annually & $\begin{array}{l}\text { Could be given regardless of } \\
\text { the CD4 cell count }\end{array}$ \\
\hline $\begin{array}{l}\text { Japanese } \\
\text { Encephalitis } \\
\text { Inactivated vero } \\
\text { cell derived }\end{array}$ & At risk & $\begin{array}{l}\text { Two doses 1month } \\
\text { apart }\end{array}$ & $\begin{array}{l}\text { One booster dose } 1 \text { to } 2 \\
\text { years later for those at } \\
\text { continued risk with a } \\
\text { further boost after } 10 \\
\text { years. }\end{array}$ & $\begin{array}{l}\text { Could be given regardless of } \\
\text { the CD4 cell count }\end{array}$ \\
\hline $\begin{array}{l}\text { Meningococcal } \\
\text { (conjugated) }\end{array}$ & At risk & $\begin{array}{l}\text { Two doses } 2 \text { months } \\
\text { apart }\end{array}$ & Five yearly if at risk & $\begin{array}{l}\text { Could be given regardless of } \\
\text { the CD4 cell count }\end{array}$ \\
\hline MMR & $\begin{array}{l}\text { To all non } \\
\text { immune }\end{array}$ & $\begin{array}{l}\text { Two doses at least } 1 \\
\text { month apart }\end{array}$ & None & $\begin{array}{l}\text { Could be given when the CD4 } \\
\text { cell count is }>200 \text { cells } / \mu \mathrm{L}\end{array}$ \\
\hline $\begin{array}{l}\text { Pneumococcal } \\
\text { (polysaccharide) } \\
\text { PPSV23 and } \\
\text { Pneumococcal } \\
\text { (Conjugate)- } \\
\text { PCV13/10 is } \\
\text { preferred }\end{array}$ & For all & $\begin{array}{l}\text { One dose of PCV13/10 } \\
\text { followed by one dose of } \\
\text { PPSV23 at least } 8 \text { weeks } \\
\text { later. Second dose of } \\
\text { PPSV23 at least } 5 \text { years } \\
\text { after the previous dose. } \\
\text { One final PPSV23 at } 65 \\
\text { years or older4. }\end{array}$ & None & $\begin{array}{l}\text { Could be given regardless of } \\
\text { the CD4 cell count }\end{array}$ \\
\hline Rabies vaccine & $\begin{array}{l}\text { For exposed non } \\
\text { immune }\end{array}$ & $\begin{array}{l}\text { Rabies immunoglobulin } \\
+ \text { five doses of the } \\
\text { vaccine IM at } 0,3,7,14 \\
\text { and } 30 \text { days }\end{array}$ & None & $\begin{array}{l}\text { Could be given regardless of } \\
\text { the CD4 cell count }\end{array}$ \\
\hline $\begin{array}{l}\text { Tetanus-Diphtheria } \\
\text { (aTd) }\end{array}$ & $\begin{array}{l}\text { To all non } \\
\text { immune }\end{array}$ & $\begin{array}{l}\text { Five doses at } 0,1,2 \\
\text { months,5 years and } 10 \\
\text { years }\end{array}$ & Ten yearly if at risk & $\begin{array}{l}\text { Could be given regardless of } \\
\text { the CD4 count }\end{array}$ \\
\hline Tetanus toxoid & $\begin{array}{l}\text { To all non } \\
\text { immune }\end{array}$ & $\begin{array}{l}\text { Five doses at 0,1,2 } \\
\text { months,5 years and } 10 \\
\text { years }\end{array}$ & Ten yearly if at risk & $\begin{array}{l}\text { Could be given regardless of } \\
\text { the CD4 count }\end{array}$ \\
\hline $\begin{array}{l}\text { Typhoid Vi Capsular } \\
\text { polysaccharide }\end{array}$ & At risk & Single dose & Three yearly if at risk & $\begin{array}{l}\text { Could be given regardless of } \\
\text { the CD4 count }\end{array}$ \\
\hline Varicella & All non immune & $\begin{array}{l}\text { Two doses } 3 \text { months } \\
\text { apart }\end{array}$ & None & $\begin{array}{l}\text { Could be given when the CD4 } \\
\text { cells count is }>200 \text { cells } / \mu \mathrm{L}\end{array}$ \\
\hline Yellow fever & $\begin{array}{l}\text { At risk } \\
\text { age }<60 \text { years } \\
\text { and } C D 4 \text { cell } \\
\text { count is }>200 \\
\text { cells } / \mu \mathrm{L}\end{array}$ & Single dose & Ten yearly if at risk & $\begin{array}{l}\text { Age }>60 \text { years, CD4 cell count } \\
\text { is }<200 \text { cells } / \mu \mathrm{L} \text { and pregnant } \\
\text { women should not receive the } \\
\text { vaccine }\end{array}$ \\
\hline
\end{tabular}


***Yeast based vaccine $40 \mu \mathrm{g} /$ dose

Acknowledgement

I gratefully acknowledge the support and the guidance given by the editorial board of SLMA Guidelines and information on vaccines book- $6^{\text {th }}$ edition 2017.

\section{References}

1. British HIV Association.BHIVAguidelines on the use of vaccines in HIV-positive adults 2015. http:// www.bhiva.org/documents/Guidelines/Vaccination /2015-Vaccination-Guidelines(accessed 28/01/2017)

2. Calles NR, Schutze GE. Immunization for children with HIV/AIDS. http://bipai.org/Curriculums/HIVCurriculum/ Immunizations-for-Children-withHIV/AIDS. aspx (accessed 30/01/2017)

3. AIDS info. Guidelines for the prevention and treatment of opportunistic infections amongHIVexposed and HIV-infected children. http:// aidsinfo .nih.gov/guidelines (accessed 30/01/2017)

4. Centers for disease Control and prevention. Pneumococcal vaccine timing for adults._https:// www.cdc.gov/vaccines/vpd/pneumo/downloads/p neumo-vaccine-timing.pdf_(accessed 10/01/2017) 